\title{
An Overview of Neglected, but Important Factors Affecting Employee's Productivity, Health and Safety in the Workplace
}

\author{
Oyesola Animashaun
}

Kola O. Odeku

\author{
Faculty of Management and Law, University of Limpopo, Turfloop, South Africa
}

\author{
Doi:10.5901/mjss.2014.v5n20p2967
}

\begin{abstract}
Majority of the people tend to spend quite an ample amount of time in their workplaces. Depending on the working hours in each jurisdiction, workers spend between eight to ten hours at work. Furniture, equipment, lights and devices are usually put in place to facilitate and improve work environment. The importance of furniture and infrastructure, the way and manner they are designed and placed, and the environmental conditions of the workplace become crucial when linked to the comfort or discomfort of the user. Poorly arranged office furniture and infrastructure can definitely be a source of reduction in productivity and output in the workplace. This article looks at the dynamic nature of furniture and office infrastructure as well as environmental conditions in the workplace, by assessing whether they have significant impact or are impediment to the day to day running of business ventures.
\end{abstract}

Keywords: Office furniture, Convenience, Workforce, Impediment, Productivity.

\section{Introduction}

Workplace furniture comprises of desks, chairs, the filing cabinet shelves, drawers, lights, noise and many others.. All these components have a specific role to play in the proper functioning of any office, the productivity and the efficiency of the employees (Charles et al. 2004) When considering various options of equipping an office, it is imperative that the office furniture should be those that are ergonomic (Wilks et al. 2006). Ergonomics is simply defined as the science of work (Wilson RW 2000). According to Adams (2014) "ergonomics derives from two Greek words: ergon, meaning work, and nomoi, meaning natural laws. Combined they create a word that means the science of work and a person's relationship to that work." As a principle, it is also known as the science of fitting the work to the user instead of forcing the user to fit the work (Pheasant and Haslegrave, 2005). In the work place the essence and need for ergonomics are to ensure maximisation of productivity by reducing operator fatigue and discomfort (Bridger, 2008). It is also referred to biotechnology, human engineering, human factors engineering ( Boff, 2006). The overall benefits to the workers in the workplace are to make products and tasks comfortable and efficient for the user (Peter et al. 2006).

The choice of workplace furniture is important, because an employee needs them to function effectively in the office (Schriefer, 2005). If the furniture are uncomfortable and not user friendly, the employee's working style, efficiency and health is affected (Rantanen, 2013). Sometimes, the health problems of employees might have an adverse effect on their productivity, making them more susceptible to errors that may lead to disaster (Clarke and Cooper, 2004). Ergonomic workplace furniture ensures that each employee blends well with things around him, like desks, chairs, computer alignment, including environmental factors (McKeown, 2007). The Employees' works are bound to be affected, if they are uncomfortable due to any reason in the workplace (Freeman, 2010). If all factors surrounding an employee are ergonomically correct, then the employee will be comfortable and remain motivated to give the best (Larsson and Gard, 2003). These days' organizations consult, and even employ ergonomic experts that advice people on how to improve their office ergonomics and what type of furniture would be suitable to make the ergonomics of a work place better (McKeown, 2007). Having ergonomic office furniture reduces the risk of injury (Fabrizio, 2009). They are designed in manner that make them safe and reduce the possibility of accidents in the work place (Pheasant and Haslegrave, 2005). Workplace furniture like desks can be designed to give more leg room and adequate support to the elbows while working on the computer ((Fabrizio, 2009). The positioning of the computer monitor and the mouse should also be comfortable and convenient, so that the user does not have to strain their eyes to view the computer screen or and stretch uncomfortably far to reach the mouse and the monitor (Timoteo-Afinidad, 2011). Office furniture must not be clustered 
together so as to avoid friction and disaster in the workplace (Worthington, 2013). They should be arranged in such a way as to allow easy ingress and egress (Kroemer, 2001). Workplace furniture helps the organization tremendously in increasing its productivity, and at the same time taking care of the employees' health (Bailyn, et al. 2003).

\section{Workplace Noise}

Workplace noise is probably the most frequently forgotten environmental pollutants with possible far-reaching effects ( Ashford, 1976). Noise, harms us in more ways than we can think of, and at times, without us even knowing about it (Schwartz, 2004). We cannot have a noise free world, but we can have a noise safe world (De Long et al. 1990). There are various sources of noise pollution. In some places, noise from construction projects predominate, while in others it is vehicular traffic noise or noise from airports ( Baranzini and Ramirez, 2005). Other noise pollutants include noise from occupational settings and conversations (Murphy and King, 2014). In Nigeria for an example, unleashed loudspeakers churches, mosques or entertainment events disturb the neighborhood endlessly day and nights.

Workplace noise poses some serious concerns. Workplace acoustics affects employee's health and safety ( Leather et al. 2003). Many studies acknowledge that noise (even at low levels), is a cause of stress that leads health problems such as digestive disorders, headache, hypertension, and ulcers (Bambra, 2011). The health status of employee is directly proportional to the productivity (Burton et al. 2005). Therefore, unhealthy employees are a cause of concern as their health issues could lead to higher disposition to committing errors that may lead to industrial accidents and hazards (Robertson and Cooper, 2011). One of the most important aspects of a well-planned office is the ability to conduct work without distraction (Brennan et al. 2002). Against this backdrop, architects and interior designers have a big and profound responsibility to design functional and sound safe environments (Piotrowski and Rogers, 2010). It is very difficult, if not impossible to meet these goals without considering acoustics (Schodek et al. 2009). Acoustics is essential to the functioning of almost every type of environment ( Parsons and Jones, 2000). Some environments can even become dangerously loud and unsafe for the occupants (Sundstrom and Sundstrom, 1986). In order to effectively address these issues, acoustics should be considered in the design phase itself (Sundstrom and Sundstrom, 1986). If workspace does not meet the needs of the end user, or is found to be unsafe, the organisation could be putting the workforce in danger (Barnes, 2001).

Very often, in the workplace environment, noise does not produce visible results (Goleman, 2000). That is probably why people believe that noise does not cause health hazards, however, it does (Cohen S, Weinstein, 1981). For examples it can create health hazards that could cause partial or total hearing loss (Anticaglia and Cohen, 1970). Noise can cause irritation, annoyance, anxiety, anti-social behavior, hostility and violence (Burney, 2009).

When designing an open office, it is important to always consider the acoustic impact of the materials being used (Haapakangas et al. 2011). In planning the layout of the workplace how the job types are being grouped, sound masking, the type of telephones used, panel heights and ceiling systems are to be considered (Marquardt et al. 2002). However, effort to control office noise through sound masking system, more absorbent surfaces and behavioural control have been weakened by increasing office densities and collaborative work in modern workspace (Vischer 2006).

Today, with the endless options in acoustic themes, and the widened horizon of designers, who now combine architecture with acoustic designing, an acoustically perfect, well-furnished office could be designed (Hoffman-Ruddy et al. 2001). This will take care of noise and also give the visual delight of perfect interior designing.

\section{Light Intensity in the Workplace}

Until recently, the only purpose of indoor lighting was to aid vision, so that visually directed tasks could be accomplished when there was not enough external light ( Anshel, 2002). A recent discovery has however shown that, light has an impact beyond merely helping us to see (Shaywitz, 2008). Non-visual receptors in the retina of the eye form nerve pathways that directly influence our biological clock, the part of our brains that controls and moderates sleep and wakefulness, directly affecting our levels of alertness (Anzi, 2009).

Light is an important therapy treatment for individuals who suffer from Seasonal affective disorder (SAD) (Lam, 1998). SAD includes depressive symptoms experienced by approximately six out of one hundred people in the developed world (Moscovitch et al. 2004). Depressive symptom occurs primarily in the autumn and winter months, when the days are shorter. Some studies show as much as 10 percent of people affected by depressive symptoms (Anzi 2009).

$S A D$ is a type of clinical depression related to morning light deprivation, usually in the late fall and winter days (Magnusson and Boivin, 2003). It is an acute depression, which can be a serious, life threatening condition. Thus it 
requires medical advice ( Morris, 2002). Treatment of SAD consists of exposure to high light levels for 30 minutes each day, preferably before 10:00 a.m (Anzi, 2009).

It is now being suggested that modern working conditions can make these symptoms worse, as many workers spend the majority, if not all daylight hours indoors, exposed to little, if any, natural light (Edwards and Torcellini, 2002). Common knowledge, backed up by scientific research proves that the quality of indoor lighting in the office can have significant effects on the performance and the well-being of employees (Anzi 2009).

In the recent years, the understanding of how light impacts upon our health have grown by leaps and bounds (Rheingold, 1993). The brightness of office light effects alertness, concentration, and task performance (Chellappa et al. 2011). Adjusting the type and quality of light can significantly improve working experience, health and productivity (Anzi, 2009).

Over-lighting or under-lighting can actually make a workplace uncomfortable and distracting (Anshel, 2002). In addition, giving workers control over their lighting has been demonstrated to increase productivity and workplace satisfaction (Newsham et al. 2006).

Newer technologies such as T8 lamps with electronic ballasts increase lighting output, eliminate flickers, offer an excellent color rendition (have a high Color Rendering Index) and save energy (Clinton, 2008). Direct and indirect linear suspended fixtures eliminate glare and increase the visual comfort of the occupants (Rizzo et al. 2010). Dimmable intelligent lighting systems allow the user to control light levels and save energy (Pan et al. 2008).

Using direct lighting to illuminate specific areas instead of relying on ceiling fixtures that brightening entire rooms is an innovative idea (Descottes and Ramos, 2013). Task lamps and desk lamps are essential pieces of office equipment, offering workers the control they need to be comfortable and productive, while reducing energy use (DiLouie, 2006). Dimmers, sensors and multiple switches also enable varied lighting levels to match needs (DiLouie, 2006). Giving workers control over their lighting has been found to result in energy saving and increased workplace satisfaction (John et al. 1988).

Workers who use computer display terminals typically prefer relatively low lighting levels to minimize glare and reflections on their display screens (Osterhaus, 2005). On the other hand, workers who read, write and draw on paper typically prefer higher lighting levels so they can see small letters and fine details (Irlen, 2005). Older workers, and others with weak vision, also need higher lighting levels (Silverstein, 2008). The ability to adjust lighting levels is particularly important for workers seated near windows, who must adapt to varying levels of sunlight during the day, and workers who require adjusted lighting levels for the different daily tasks that they perform ( Galasiu et al. 2006).

\section{Sky Effect ${ }^{\mathrm{TM}}$ Technology}

With the understanding of how light affects our bodies, Nature Bright has created a new generation of industrial lighting (Mills and Tomkins, 2007). The Sky Effect ${ }^{\mathrm{TM}}$ range of fluorescent lights are specially designed for office and factory use. Unlike conventional lights, these, deliver a far broader spectrum of light (DiLouie, 2011). These new lights incorporate greater levels of shorter wavelength light-light in the blue range of the spectrum (Blackwel et al. 2004). This blue light has been shown to have the greatest effects upon our central biological clock (Froehlich et al. 2002). It also happens to be precisely the spectrum of light that is missing in conventional indoor lighting (Michel, 1995).

This light is only slightly different in appearance to conventional lights. Its brightness is exactly the same and its clarity is pleasing to the eye (Loe and Rowlands, 1996). Sky Effect ${ }^{\mathrm{TM}}$ lights are described as having a "higher color temperature" than conventional lights (Mueller et al. 2003). And this higher temperature results in a brighter light for the workers (Wei et al. 2013). The benefits of Sky Effect ${ }^{\mathrm{TM}}$ are that it : increases focus, alertness, and concentration boost performance, fends off fatigue, reverses $S A D$, minimizes lost work time and maximizes productivity (Scarbrough AW 2008).

\section{Temperature and Humidity}

Currently, there are no regulations governing temperature levels in the workplace, and the responsibility of employers to their employees in this respect (Weiler, 2009). The World Health Organization, however, recommends a maximum working temperature of $24^{\circ} \mathrm{C}$ (Kazmierczak and Connelly, 2012).

During working hours, the temperature in all enclosed workplaces should be reasonable (Roelofsen, 2002). Temperature alone does not ensure 'reasonable' comfort (Schumann and Burillo, 2010). Other factors such as air movement and relative humidity also have a role to play (Ye et al. 2003). In work environment like in Nigeria, where 
temperature is high throughout the year, there is a need to install air conditioners and fans in the workplace to make the environment habitable (Arens et al. 2005).

The possible effects of high temperature is, employee lethargy and tiredness, as a result of increased body temperature which leads to possible efficiency decrease, while low temperature levels decreases efficiency due to lower body heat and shivering: ( Dhillon S 2012).

High humidity in itself may not be a direct problem, but it does increase susceptibility to high temperature levels, as evaporation of body sweat is impeded ( Dhillon, 2012).

Low humidity levels have a debilitating effect on the ability to breathe and swallow without discomfort as the mouth and nose can become dry, due to the increased level of evaporation in the surrounding environment (Maskin, 2007).

Temperature and humidity can have a significant impact on how alert or tired somebody might feel (Zhang et al. 2010). This, in turn, can have a dramatic effect on the health of the worker (Krauss et al. 2003). In hot environments, it is not uncommon for staff to become irritable and less efficient (McCoy and Evans, 2005). It can be very easy for employers to underestimate the importance of general day-to-day comfort (Molloy, 2005). A lot of emphasis has been placed, in recent years, on issues such as maximum working hours, ergonomically designed offices and so on, but the overall comfort of the working conditions of employees can sometimes be overlooked (Antonelli, 2001).

The American Society of Interior Designers (ASID, 1999) carried out an independent study and revealed that, the physical workplace design is one of the top three factors, which affect health, performance and job satisfaction. 31 percent of people were satisfied with their jobs and had pleasing workplace environments. 50 percent of people were seeking jobs and said that they would prefer a job in a company where the physical environment is good.

\section{Towards a Safe Place of Work}

To ensure the health and safety of the workforce, and the stakeholders at the workplace, the following is pertinent: work areas should be large enough to be safe and healthy ( Hart SH 2010). General stability, good ventilation and fresh air, optimum temperature and lighting should be available (Elearn, 2006). Pedestrians and vehicles must be able to circulate safely ( Landoni and Pittiglio, 2012). Traffic routes, entrances and exits must be kept clear (Anderson, 2006). Floors, walls, ceilings, roofs, doors and gates, loading bays and ramps must be safe (Thomson, 1997).

Toilet, washing and welfare facilities must be provided (Walia, 2013). In addition, rest rooms, changing rooms and sanitary facilities, facilities for pregnant women, nursing mothers and employees with disabilities must be provided (Polychronakis et al. 2008 ).

\section{The Safe Use of Equipment}

Essential warnings and markings should be placed noticeably on work equipment ( Slater and Whelpton _ 1990). Employees should have access to written instruction and adequate information and training on its use must be given. (Lehto and Salvendy, 1995). Repairs, modifications, maintenance or servicing should be carried out only by competent persons (Tsang, 2002). There should be safe means of access for production work and for maintenance or adjustments (Hale et al. 1988).

All equipment must have proper control devices for starting and stopping ( Kemmlert and Lotta Lundholm, 2001). Guards should be placed on equipment where there is a risk from contact, or where there are high or very low temperatures (Thurman et al. 1988). Any equipment from which objects might fall must be fitted with safety devices (Howie, 2008). The containment or extraction of gas, vapour, liquid or dust emissions must be provided for (Carson, 2002). Equipment must be maintained during its working life so that it continues to comply with these requirements (Houshyar, 2004).

\section{Personal Protective Equipment (PPE)}

Wherever possible, employers must eliminate hazards in places of work at source (DeJoy and Southern, 1993). If these cannot be eliminated totally, they must be reduced to a minimum and adequately controlled (Spellman and Bieber, 2011). PPE must be provided free of charge by the employer and must be used by the employee (Booty, 2009). The personal protective equipment must be suited to the risks involved, take account of the conditions of the place of work, and be suitable to the wearer and for the work to be done (Hughes and Ferrett 2011).

Before choosing PPE, an employer must assess its suitability in relation to the risks involved (Lingard and Holmes, 
2001). The employer must also decide on the frequency of use of PPE ( Hewitt, 1998). This will take into account the seriousness and frequency of the risk. PPE must be properly maintained and stored (Sargent and Gallo, 2003). Normally, only one employee will use any individual piece of personal equipment. Employees must be specifically informed of the risks for which the PPE is provided. They must be properly instructed and trained in its use, using demonstrations if appropriate (Liedtke, 2005). Information, training and consultation on safety and health must take these requirements into account.

\section{Visual Display Units (VDUs)}

The regulations cover not just the VDU itself but the operator, the desk, chair and the surrounding area (Marriott and Stuchly, 1986). All workstations must be designed to suit the tasks carried out at them (Toomingas, 2006). The specific requirements for VDUs cover the work environment (including noise, heat and humidity), the display screen (including reflection and glare), the keyboard, desk or work surface, chair and the operators positioning in front of the VDU. The employer must analyse each workstation including the environment (space requirements, lighting, reflections, glare and radiation) and the equipment itself- the display screen, the keyboard and the software in use (Anshel, 2002). Adequate breaks from screen work must be arranged. All employees using VDUs will be entitled to eye tests and spectacles if they are needed for their work and must be advised by their employer of their right to such eye tests (Howard, 2013).

\section{Conclusion}

The health and safety of employees should be paramount in any workplace. Employers always seek huge output and many dividends, which are essential for the continuation of business ventures. However, this cannot be achieved if the employees are not healthy and comfortable in their workplaces. These sorts of return on investments will only become realistic and achievable if the essential infrastructure such as furniture and other office equipment and suitable environmental conditions-lighting, health, noise control, safety that are needed are provided. This is because they are the major tools that will be deployed for the purposes of making the business a going concern. The work environment should thrive as much as possible to provide and include suitable and convenient office infrastructure and comfortable environmental working conditions that will make the job easier and keep the employees in good health.

\section{References}

Anderson T 2006. Vehicles at work: health and safety in the workplace-Pedestrian walkways and cycleways. http://www.hse.gov. uk/workplacetransport/factsheets/segregation.htm. (Retrieved on 4 May, 2012).

Anshel J 2002. Visual ergonomics in the workplace. From http://books.google.co.za/books?hl=en\&lr=\&id=bxQeR8UTL-kC\&oi=fnd\&pg= PP11\&dq= sig=YDB65iLz1x7zSa2EaMpllOPen30\#v=onepage\&q\&f=false. (Retrieved on 2 December, 2012).

Anshel J 2002. Visual ergonomics in the workplace. Taylor \& Francis, London, UK

Anticaglia JR, Cohen A 1970. Extra-Auditory Effects of Noise as a Health Hazard. American Industrial Hygiene Association Journal, 31(3): 277-281.

Antonelli P 2001. Workspheres: design and contemporary work styles. From http:// hl=en\&lr=\&id=lisaupsmlqcc\&oi=fnd\&pg=pa6\&dq=a+ . (Retrieved 16 May, 2012). gawik76jam\&sig=vugzd7nosdhmbqhffegbqmnfvsO\#v=onepage\&q\&f=false. (Retrieved on 8 January, 2012).

Anzi M 2009. Workplace Environment and its impact on employees performance. Open University Of Malaysia.

Arens E CC Federspiel D, Huizenga WC 2005. How Ambient Intelligence will Improve Habitability and Energy Efficiency in Buildings, 1: 63-80.

Ashford NA 1976. Crisis in the Workplace: Occupational disease and injury: a Report to the Ford Foundation. New York, UK:Ford Foundation.

Audrey Ellison Schriefer Workplace strategy: What it is and why you should care. Journal of Corporate Real Estate, 7(3): 222 - 233.

Bailyn L, JK Fletcher, D Kolb 2003. Unexpected connections: Considering employees' personal lives can revitalize your business. From. http://books.google.co.za/books?hl=en\&lr=\&id=az_ucjtgrsgc\&oi=fnd\&pg=pa375\&dq= =hqgihptq4isihlogioszjv_e_a8\#t=onepage\&q\&f=false. (Retrieved on 29 March, 2012).

Bambra C 2011. Work, worklessness, and the political economy of health. Oxford, UK: Oxford University Press.

Baranzini A, Ramirez JV 2005. Paying for quietness: the impact of noise on Geneva rents. Urban studies, 42(4): 633-646.

Barnes P, 2001. Regulating safety in an unsafe world (risk reduction for and with communities). Journal of Hazardous Materials. 68(1-3): 25-37.

Blackwell M, Dowling K, Morgan F 2004. Methods and systems for medical lighting. From http://www.google.com/patents IUS20050099824. (Retrieved on 25 January, 2012). 
Blackwell M, K Dowling, F Morgan 2004. Methods and systems for medical lighting. From. http://www.google.com/patents IUS20050099824. (Retrieved on 29 May, 2013).

Boff KR 2006. Revolutions and shifting paradigms in human factors \& ergonomics. Applied Ergonomics. 37(4):391-399.

Booty F 2009. Facilities management handbook. Routledge, New York, USA.

Boyce PR 2004. Lighting research for interiors: the beginning of the end or the end of the beginning. Lighting Research and Technology, 36(4): 283-293.

Brennan A, Chugh JS, Kline T 2002. Traditional versus Open Office Design A Longitudinal Field Study. Environment and Behavior, 34(3):279-299.

Bridger R 2008. Introduction to ergonomics. Taylor \& Francis, New York, USA

Burney E 2009. Making people behave: Anti-social behaviour, politics and policy. Willian Publishing, Devon, UK.

Burton W N, Chin-Yu C, Conti DJ, Schultz AB, Pransky G, Edington D W, 2005. The association of health risks with on-the-job productivity. Journal of Occupational \& Environmental Medicine, 47(8): 769-777.

Carson PA 2002. Hazardous chemicals handbook. From http://books.google.co.za/books?hl=en\&lr=\&id=jmyl2BxBj VAC\&oi=fnd\&pg= PP2\&dq=in+W5fePzHDWZ\&sig=DLp0241fEjm5pR1CtlyrKnG7FnU\#v=onepage\&q\&f=false. (Retrieved on 14 June, 2012).

Charles KE, Danforth A, Veitch JA, Zwierzchowski C 2004. Workstation design for organizational productivity. From http://nparc.cistiicist.nrc-cnrc.gc.ca/npsi/ctrl?action=rtdoc\&an=20377787. (Retrieved on 16 May, 2013).

Chellappa SL, R Steiner, P Blattner, P Oelhafen, T Götz... - PLOS One, 2011. Non-visual effects of light on melatonin, alertness and cognitive performance: can blue-enriched light keep us alert? From http://www.plosone.org/article/info\%3Adoi\% 2F10.1371\%2Fjournal.pone.0016429. Retrieved on 23 November, 2013).

Chronobiology international, 20(2):189-207

Clarke S, Cooper CL 2004. Managing the risk of workplace stress: Health and safety hazards. From http://books.google.co.za/books?hl=en\&|r=\&id=a9aojwrhk8wc\&oi=fnd\&pg=pr9\&dq=-wexeh4\&sig=zvx-k1emyon-st8lf1j4h0da9a0 $\# \mathrm{v}=$ onepage \&q\&f=false. (Retrieved on 26 August, 2012).

Clinton MB 2008. A fundamental study on current industrial lighting systems and analyses of retrofit options. From http://www.me.ua.edu/me416/s09/pdf/Lighting.pdf. (Retrieved on 11 April, 2012).

Cohen S, Weinstein N 1981. Nonauditory Effects of Noise on Behavior and Health. Journal of Social Issues. 37(1):36-70.

Cotton JL, Vollrath DA, Froggatt KL, Lengnick-Hall ML, Jennings KR 1988. Employee participation: Diverse forms and different outcomes. Academic Management Review, 13(1): 18-22.

Cotton JL, DA Vollrath, KL Froggatt, Saval N 2014. Cubed: A secret history of the workplace. New York, USA:Doubleday.

De Long JB, Andrei Shleifer, Lawrence H. Summers and Robert J. Waldmann 1990. Noise Trader Risk in Financial Markets. Journal of Political Economy, 98(4): 703-738.

DeJoy DM, Southern DJ 1993. An integrative perspective on work-site health promotion. From http://journals.Iww.com/joem/abstract /1993/12000/an_integrative_perspective_on_work_site_health.17.aspx. (Retrieved on 11 November, 2012).

Descottes H, Ramos CE 2013. Architectural Lighting: Designing with Light and Space. New York, USA:Princeton Architectural Press.

Dhillon S 2012. Environmental Hazards, Hot, Cold, Altitude, and Sun. Infectious Disease Clinics of North America, 26(3):707-723.

Dhillon S 2012. Infectious Disease Clinics of North America. Environmental Hazards, Hot, Cold, Altitude, and Sun. 26(3): 707-723.

DiLouie C 2006 . Advanced lighting controls: energy savings, productivity, technology and applications. Academic Management Review, 13(1): 8-22.

DiLouie C 2011. Lighting Redesign for Existing Buildings. Taylor \& Francis, Florida, USA.

Edwards L, Torcellini PA 2002. A literature review of the effects of natural light on building occupants. From http://ccssolarenergy.net/natural_light.pdf. (Retrieved on 13 March, 2013).

Elearn E 2006. Managing Health, Safety and Working Environment. From http://books.google.co.za/books?hl=en\&lr=\&id=wpcljchs 9kgc\&oi=fnd\&pg=pt4\&dq=to+gh\&ots=w6m2hnflq6\&sig=yytsriwb1t1sbgywnogskht8vmw\#v=onepage\&q\&f=false. (Retrieved on 6 Aogust, 2013).

Fabrizio P 2009. Ergonomic intervention in the treatment of a patient with upper extremity and neck pain. Physical Therapy, 89(4): 351360.

Freeman RE 2010. Strategic management: A stakeholder approach. Cambridge, UK: Cambridge University Press.

Froehlich AC, Y Liu, JJ Loros, JC Dunlap - Science, 2002. White Collar-1, a circadian blue light photoreceptor, binding to the frequency promoter. Science, 297(2):815-819.

From http://www.theseus.fi/handle/10024/69703. (Retrieved on 26 May, 2014).

Galasiu AD, Jennifer A. Veitch 2006. Occupant preferences and satisfaction with the luminous environment and control systems in daylight offices: a literature review. Energy and Buildings, 38(7): 728-742.

Goleman D 2000. Leadership that gets results. Harvard business review, 2000. From http://www.edplus.canterbury.ac.nz/school_ leadership/documents/hbr_leadership_gets_results_(goleman).pdf. (Retrieved on 16 September, 2013).

Haapakangas A.; Kankkunen, E.; Hongisto, V.; Virjonen, P.; Oliva, D.; Keskinen, E. 2011. Effects of five speech masking sounds on performance and acoustic satisfaction. Implications for open-plan offices, Acta Acustica, 97(4): 641-655.

Hale AR, B.H.J. Heming, K. Smit, F.G.Th. Rodenburg, N.D. van Leeuwen 1988. Evaluating safety in the management of maintenance activities in the chemical process industry. Safety Science. 28(1): 21-44.

Hart SH 2010. Self-regulation, Corporate Social Responsibility, and the Business Case: Do they Work in Achieving Workplace Equality and Safety? Journal of Business Ethics, 92(4): 585-600. 
Hewitt S 1998. Assessing the Performance of Anti-vibration Gloves-A Possible Alternative to ISO 10819, 1996. Annual Occupational Hygiene 42 (4): 245-252.

Hoffman-Ruddy B, Jeffrey Lehman, Carl Crandell, David Ingram, Christine Sapienza 2001. Laryngostroboscopic, Acoustic, and Environmental Characteristics of High-Risk Vocal Performers, Journal of Voice, 15(4): 543-552.

Houshyar A 2004. Reliability and Maintainability of Machinery and Equipment, Part 1: Accessibility and Assessing Machine Tool R\&M Performance. From http://www.actapress.com/Abstract.aspx?paperld=20622. (Retrieved on 12 April, 2012).

Howard GS 2013. Legal aspects of fitness for work- Fitness for Work: The Medical Aspects, Oxfrod University Press, Oxford, UK.

Howie RM 2008. Personal protective equipment - Occupational hygiene. http://books.google.co.za/books?hl=en\&lr=\&id=bn1_ xemovkic\&oi=fnd\&pg=pa460=yurgo1y7ee\&sig=wrk139xapc8pgmdm20wfngdofji\#v=onepage\&qf=false.

(Retrieved on 11 January, 2012).

http://books.google.co.za/books?hl=en\&lr=\&id=0z4owbwkoxac\&oi=fnd\&pg=pa1\&dq==enqm8yqlhj\&sig=-smj_ub87exjtz5n4srrs4ycep4 \#v=onepage\&q\&f=false. (Retrieved on 2 May, 2012).

http://books.google.co.za/books?hl=en\&lr=\&id=fr8bdudisqac\&oi=fnd\&pg=pr11\&dq=in+=ujwazat0xb\&sig=cdx9ofuckp2tukm7b31obehidlk $\# v=$ onepage \&q\&f=false. (Retrieved on 12 January , 2012).

http://books.google.co.za/books?hl=en\&|r=\&id=phny1sjfae8c\&oi=fnd\&pg=pr13\&dq=\&ots=stohlon3vs\&sig=fftfqvdu_vn5vb 0iqyms4a98tuq $\# \mathrm{v}=$ onepage \&q\&f=false. (Retrieved on 29 July, 2012).

http://books.google.co.za/books?hl=en\&lr=\&id=xivdc4-pcfac\&oi=fnd\&pg=pp1\&dq=zdntt92pb5\&sig=kyf1jlluwuzarjcgxedjsnj1dpk\#v=one page\&q\&f=false. (Retrieved on 15 June, 2012).

(Retrieved on 14 July, 2012).

Hughes P, E Ferrett 2011. Introduction to health and safety at work Butterworth Heinemann, Oxford, UK.

Irlen $\mathrm{H}$ 2005. Reading by the colors: Overcoming dyslexia and other reading disabilities through the Irlen method. New York, USA: The Berkeley Publishing Group.

Kazmierczak A, Connelly A 2012. Adaptation to weather and climate in office buildings in Manchester. From http://media.adaptingmanchester.co.uk.ccc.cdn.faelix.net/sites/default/files/Adaptation_to_weather_and_climate_in_office_buildin gs.pdf. (Retrieved on 17 January, 2013).

Kemmlert K, Lotta Lundholm 2001. Slips, trips and falls in different work groups - with reference to age and from a preventive perspective. Applied Ergonomics. 32(2): 149-153.

Krauss AD, PY Chen, S DeArmond 2003. Sleepiness in the workplace: Causes, consequences, and countermeasures. Sussex, UK: John Wiley \& Sons, Ltd.

Kroemer KHE 2001. Office ergonomics. New York, USA:Taylor \& Francis Ltd.

Landoni, P Pittiglio 2012. Industrial Site Workplace Transport and Safety Management From http://www.aidic.it/cet/12/26/100.pdf. (Retrieved on 29 September, 2013).

Larsson A, Gard G 2003. How Can the Rehabilitation Planning Process at the Workplace Be Improved? A Qualitative Study From Employers' Perspective. Journal of Occupational Rehabilitation, 13(3): Employers, 169-181.

Leather P, Diane Beale, Lucy Sullivan 2003. Noise, psychosocial stress and their interaction in the workplace. Journal of Environmental Psychology. 23(2): 213-222.

Lethom S G 1995. Warnings: a supplement not a substitute for other approaches to safety. Ergonomics, 38(11): 2155-2163.

Liedtke M 2005. Risk by use of hearing protectors--expert programme supports SMEs in appropriate selection and use. Noise and Health, 7(26): 31-37.

Lingard $\mathrm{H}$, Holmes N 2001. Understandings of occupational health and safety risk control in small business construction firms: barriers to implementing technological controls. Construction Management and Economics. 19(2):217-226.

Loe DL, Rowlands E 1996. The art and science of lighting: A strategy for lighting design. Lighting Research and Technology, 28(4): 153164.

Magnusson A, Boivin D 2003. Seasonal Affective Disorder: An Overview. Review, 20(2):189-207. Marquardt CJG, Veitch JA, Charles KE 2002. Environmental satisfaction with open-plan office furniture design and layout. From http://archive.nrc-cnrc.gc.ca/obj/irc/doc/pubs/rr/rr106/rr106.pdf. (Retrieved on 11 February, 2013).

Marriott IA, MA Stuchly 1986. Health aspects of work with visual display terminals. Fom http://journals.Iww.com/joem/abstract/ 1986/09000/health_aspects_of_work_with_visual_display.15.aspx. (Retrieved on 1 April, 2012).

Maskin SL 2007. Reversing dry eye syndrome: practical ways to improve your comfort, vision, and appearance. from . http://books.google.co.za/books?hl=en\&lr=\&id=kpwowkzfhwkc\&oi=fnd\&pg= vironment\&ots=iv567irej3\&sig=isbavpivmordnufmpqoukxk0-A8\#v=onepage\&q\&f=false. (Retrieved on 7 January, 2012).

McCoy JM, Evans GW 2005. Physical work environment - Handbook of work stress. California, USA:

McKeown C 2007. Office ergonomics: practical applications. From http://books.google.co.za/books?hl=en\&lr=\&id=xivdc4-pcfac\&oi=fnd\& pg=pp1\&dq=these+days\%e2\%80\%99+=zdntt92ty-\&sig=f-gm95uxmq-hys26nq5lke-qghg\#v=onepage\&q\&f=false. (Retrieved on 9 July, 2012).

Michel L 1995. Light: the shape of space: designing with space and light. From http://books.google.co.za/books?hl=en\&lr=\&id= yhzamdsifhqc\&oi=fnd\&pg=pa21\&dq=in00j1navks9\&sig=mncifm2ammtsqnru0yuqe 2 mpega\#v=onepage\&q\&f=false. (Retrieved on 9 July, 2012).

Mills PR, Tomkins SC 2007. The effect of high correlated colour temperature office lighting on employee wellbeing and work performance. Journal of Circadian Rhythms, 5(2): 1740-1755. 
Molloy A 2005. Stop Living Your Job, Start Living Your Life: 85 Simple Strategies to Achieve Work/Life Balance. California, USA: Ulysses Press.

Morris DB 2002. Light as Environment: Medicine, Health, and Values. Journal of Medical Humanities. 23(1):7-29.

Moscovitch A, Carl A. Blashko, John M. Eagles, Guy Darcourt, Christopher Thompson, Siegfried Kasper, Roger M. Lane 2004. A placebo-controlled study of sertraline in the treatment of outpatients with seasonal affective disorder. Psychopharmacology. 171(4): 390-397.

Mueller GG, AD Ducharme, KJ Dowling 2003. Methods and apparatus for generating and modulating white light illumination conditions. From http://www.freepatentsonline.com/y2003/0133292.html. (Retrieved on 2 May, 2013).

Murphy E, King E 2014. Environmental Noise Pollution: Noise Mapping, Public Health, and Policy. California, USA. Elsivier.

Newsham GR, C Donnelly, S Mancini 2006. The effect of ramps in temperature and electric light level on office occupants: a literature review and a laboratory experiment. From http://www.nrc-cnrc.gc.ca/obj/irc/doc/pubs/nrcc41868/nrcc41868.pdf. (Retrieved on 11 January, 2012).

Osterhaus WKE 2005. Discomfort glare assessment and prevention for daylight applications in office environments, Solar Energy. 79(2): $140-158$.

Pan MS, LW Yeh, YA Chen, YH Li 2008. A WSN-based intelligent light control system considering user activities and profiles. From http://ieeexplore.ieee.org/xpl/freeabs_all.jsp?arnumber=4631434\&abstractAccess=no\&userType=inst. (Retrieved on 17 January, 2012).

Parsons S, Jones G 2000. Acoustic identification of twelve species of echo locating bat by discriminant function analysis and artificial neural networks. Journal of Experimental Biology, 1(203):2641-2656.

Peter Vink, Ernst A.P. Koningsveld, Johan F. Molenbroek 2006. Positive outcomes of participatory ergonomics in terms of greater comfort and higher productivity. Applied Ergonomics. 37(4):537-546.

Pheasant S, Haslegrave CM 2005. Bodyspace: Anthropometry, ergonomics and the design of work. CRC Press, Florida, USA.

Pheasant S, Haslegrave CM 2005. Bodyspace: Anthropometry, ergonomics and the design of work. Fromhttp://books.google.co. za/books?hl=en\&lr=\&id=nwfvsbuybdmc\&oi=fnd\&pg=pa3\&fp\&sig=ebmz72hu2mgjyhpfm0atilgvcou\#v=onepage\&q\&f=false. (Retrieved on 29 March, 2012).

Piotrowski CM, Rogers EA 2010. Designing commercial interiors. New Jersey, UK: John Wiley's \& Sons.

Polychronakis I, C Chatzis, I Kotsioni, E Riza 2008. The legal context for workplace safety and health promotion: thinking of women. From http://link.springer.com/chapter/10.1007/978-0-387-73038-7_2\#page-1. (Retrieved on 2 February, 2012).

Rantanen H 2013. Generational work environment preferences: Case Ovenia. From http://www.theseus.fi/handle/10024/69703. (Retrieved 27 August, 2014).

Rheingold $\mathrm{H}$ 1993. The virtual community: Homesteading on the electronic frontier. From

Rizzo P, Mark Rea, Robert White 2010. Lighting for Today's Neonatal Intensive Care Unit. Newborn and Infant Nursing Reviews. 10(2): $107-113$.

Robertson I, Cooper CL 2011. Well-being: Productivity and happiness at work. Hampshire, UK: Palgrave Macmillan.

Roelofsen P 2002. The impact of office environments on employee performance: The design of the workplace as a strategy for productivity enhancement. Journal of facilities Management, 1(3):247 - 264.

Lam RW 1998. Seasonal affective disorder and beyond: light treatment for SAD and non-SAD conditions. Washington USA:American Psychiatric Press Ltd.

Sargent EV, F Gallo 2003. Use of personal protective equipment for respiratory protection. ILAR Journal, 44 (1): $52-56$.

Scarbrough AW 2008. Compassion and conflict: The impact of the medicare end-stage renal disease program. From http://repositories.tdl.org/tdl-ir/handle/2152.3/271. (Retrieved on 28 June, 2013).

Schodek DL, P Ferreira, MF Ashby - 2009. Nanomaterials, nanotechnologies and design: an introduction for engineers and architects. London, UK:Elsevier.

Schriefer AE 2005. Workplace strategy: What it is and why you should care. http://www.emeraldinsight.com/doi/pdfplus /10.1108/14630010510631081. (Retrieve on 16 February, 2013).

Schumann A, M Burillo 2010. Predicting the desired thermal comfort conditions for shared offices. From. http://www.engineering. nottingham.ac.uklicccbe/proceedings/pdf/pf48.pdf. (Retrieved on 9 June, 2013).

Schwartz B 2004. The paradox of choice . From http://thoughtleaderpedia.com/Marketing-Library/Quotes/ParadoxOfChoice_Quotes.pdf. (Retrieved on 16 September, 2013).

Shaywitz S 2008. Overcoming dyslexia: A new and complete science-based program for reading problems at any level. From http://books.google.co.za/books?hl=en\&lr=\&id=jhu02hstcjsc\&oi=fnd\&pg=pa90\&dq= ts=v9du7jyrib\&sig=kgrcyyw5bwjq3syndabk8xj_qvc\#v=onepage\&q\&f=false. (Retrieved on 11 January, 2012).

Silverstein M 2008.Meeting the challenges of an aging workforce. American Journal of Industrial Medicine, 51(4): 269-280.

Slater E J, Whelpton D 1990. Handbook of Laboratory Health and Safety Measures. Sage Publication Incorporation.

Spellman FR, Bieber RM 2011. Physical Hazard Control: Preventing Injuries in the Workplace. Maryland, USA:Scarecrow Press Ltd.

Sundstrom E, Sundstrom MG 1986. Work places: The psychology of the physical environment in offices and factories. New York, UK: Press Syndicate of University of Cambridge.

Thomson AK 1997. Vehicle movement and loading bay design. From http://link.springer.com/chapter/10.1007/978-1-4613-11270_11\#close. (Retrieved on 1 October, 2012).

Thurman JE, Louzine AE, Kogi K 1988. Higher productivity and a better place to work: practical ideas for owners and managers of small 
and medium-sized industrial enterprises. From

Timoteo-Afinidad CB 2011. Workstation and workspace ergonomics in philippine libraries: an emerging priority. From http://www.journals.upd.edu.ph/index.php/jpl/article/view/2075. (Retrieved On 19 July, 2013).

Toomingas A, P Cohen, C Jonsson 2006. A Sound Working Environment in Call and Contact Centres. From http://nile.lub.lu.se/arbarch/arb/2006/arb2006_49.pdf. (Retrieved on August 8, 2012).

Tsang AHC 2002. Strategic dimensions of maintenance management. From http://www.emeraldinsight.com/doi/full/10.1108/ 13552510210420577. (Retrieved on 12 March, 2012).

Walia R 2013. An analytical study of employees welfare schemes a case study of panipat thermal plant. From http://shodhganga.inflibnet.ac.in/handle/10603/10925. (Retrieved on 8 May, 2014).

Wei M, KW Houser, B Orland, DH Lang 2013. Office worker response to fluorescent lamps of different CCT and lumen output. From http://ascelibrary.org/doi/abs/10.1061/9780784412909.054. (Retrieved on 9 April, 2014).

Weiler PC 2009. Governing the workplace: The future of labor and employment law. From http://books.google.co.za/books?hl=en\&lr= \&id=0z4owbwkoxac\&oi=fnd\&pg=pa1\&dq= id9pp1cg9ma7sxgy\#v=onepage\&q=governing\%20the\%20workplace\%3a\%20the\%20future\%20of\%20labor\%20and\%20employm ent\%20law\&f=false. (Retrieved on 26 July, 2013).

Wilks S, Monica Mortimer, Per Nylén 2006. The introduction of sit-stand worktables; aspects of attitudes, compliance and satisfaction. Applied Ergonomics. 37(3):359-365.

Wilson RW 2000. Fundamentals of ergonomics in theory and practice. Applied Ergonomics, 31(6):557-567.

Worthington J 2013. Reinventing the workplace.

From http://books.google.co.za/books?hl=en\&lr=\&id=eyijallu10ic\&oi=fnd\&pg=pp2\&dq=office+fse. (Retrieved on 19 July, 2013).

Ye G, Changzhi Yang, Youming Chen, Yuguo Li 2003. A new approach for measuring predicted mean vote (PMV) and standard effective temperature (SET). Building and Environment, 38(1): 33-44.

Zhang H, Edward Arens, DongEun Kim, Elena Buchberger, Fred Bauman, Charlie Huizenga 2010. Comfort, perceived air quality, and work performance in a low-power task-ambient conditioning system. Building and Environment, 45(1): 29-39. 